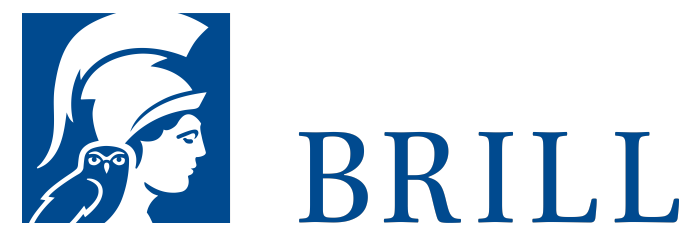

\title{
Justin Martyr and the Jews
}

\section{Author: Rokeah}

Justin Martyr, a second-century Gentile Christian apologist, was active in the Christian-Jewish propaganda war to convert each other and the pagans. He radicalized the ideas of St. Paul on the divine Election, Abraham, the Pentateuch, and the Gentiles. Justin's background, sources, and thought, and his place in the inter-religious propaganda war, are discussed, as are the irreconcilable views of Jesus and Paul on the Pentateuch and the Gentiles.

Justin Martyr and the Jews considers the place of Paul and Justin's teachings in today's Christian-Jewish dialogue about the roots of early Christian Antisemitism, showing that the presuppositions of Paul and Justin must be abandoned if Christians and Jews today are to reach true understanding. As part of the search for such understanding, recent scholarly literature has been concerned with pre- and post-Holocaust inter-religious relations, as well as with the roots of Christian Antisemitism. Some scholars have endeavoured to show that Pauline teachings were misunderstood, and thereby exonerate Paul from the responsibility for Christian persecutions of Jews through the ages. These scholars have also attempted to make Paul a bridge between Christians and Jews in their modern dialogue. The present writer argues that this interpretation of Pauline teaching, followed and even radicalized by Justin, is unfounded.

\section{Readership}

Students, scholars, and theologians interested in past and contemporary inter-religious relations, ecclesiastical history and thought, ancient history and Jewish history. It should be available in academic and public reference libraries. 
David Rokéah, Ph.D. (1968) in History, Hebrew University of Jerusalem, is Professor Emeritus of Ancient History and SecondTemple Jewish History, Hebrew University. His many publications on religious relations in the early Christian centuries include Jews, Pagans and Christians in Conflict (Brill, 1982).

For more information see brill.com

Order information: Order online at brill.com +44330 3330049 | customerservices@brill.com Submission information: brill.com/authors

Titles published by Brill | Fink, Brill | mentis or Brill | Schöningh: +49(o)71 5413279216 | brill@brocom.de 